\title{
Status of the European race of Scleroderris canker in Canada
}

\author{
by G. Laflamme ${ }^{1}$, A.A. Hopkin ${ }^{2}$ and K.J. Harrison ${ }^{3}$
}

The European (EU) race of Gremmeniella abietina (Lagerb.) Morelet, the causal agent of scleroderris canker of conifers, is a damaging pathogen in pine forests. In North America, this disease is found in the northeastern United States and in eastern Canada. Results from surveys conducted across Canada since 1979 are updating us on where this disease is found. In Newfoundland, only the EU race has been recorded and it is restricted to the Avalon Peninsula. Contrary to earlier reports in the Maritime provinces, only one pine plantation is infected by the EU race in New Brunswick. In Ontario, a total of 171 plantations are infected and they are clustered in the central portion of the southern part of the province. The number of plantations infected by the EU race in Quebec is the highest in Canada with 749 plantations. In the four provinces, the most infected species is red pine $(86 \%$ of the infected plantations), followed by two exotic species, Scots pine (9.5\%) and Austrian pine (3.2\%). White pine and jack pine show resistance to the disease.

Key words: Brunchorstia pinea, Pinus resinosa, reforestation, Scleroderris lagerbergii

\section{Introduction}

Gremmeniella abietina (Lagerb.) Morelet, the causal agent of Scleroderris canker of conifers, is a damaging pathogen in the pine forests of North America, Europe and Asia (Gibbs 1993; Laflamme 1993; Setliff et al. 1975; Yokota et al. 1974). Dorworth and Krywienczyk (1975) have identified three races of $G$. abietina based on serological tests: the North American (NA), European (EU) and Asian races. Later, these three races were confirmed to be divergent based on their ecological, etiological and molecular characteristics, but were considered morphologically indistinguishable (Bernier et al. 1994; Hamelin et al. 1993; Petrini et al. 1989; Petrini et al. 1990) and were confined to the variety abietina of the fungal species. Another variety, Gremmeniella abietina var. balsamea, has been reported on balsam fir (Abies balsamea (L.) Mill.) and native spruces (Picea spp.) $100 \mathrm{~km}$ north of Quebec City (Petrini et al. 1989). The NA and EU races are present in North America while the Asian race is reported only in Japan. The NA race is believed to be indigenous to this continent, considering its wide distribution, ecological adaptations and high levels of genetic variability (Laflamme 1993; Hamelin et al. 1993). In Canada, the NA race of the disease was first identified in 1960 from white pine (Pinus strobus L.) in Ontario (Punter 1967, Hopkin and Davis 1998). However, the disease is now known

\footnotetext{
${ }^{1}$ Natural Resources Canada, Canadian Forest Service, Laurentian Forestry Centre, P.O. Box 3800, 1055 du P.E.P.S., Sainte-Foy, Quebec GIV 4 C7.

${ }^{2}$ Natural Resources Canada, Canadian Forest Service, Great Lakes Forestry Centre, P.O. Box 490, 1219 Queen St. East, Sault Ste. Marie, Ontario P6A 5M7.

${ }^{3}$ Natural Resources Canada, Canadian Forest Service, Atlantic Forestry Centre, P.O. Box 4000, 1350 Regent Street South, Fredericton, New Brunswick E3B 5P7.
}

La race européenne (EU) de Gremmeniella abietina (Lagerb.) Morelet, l'agent causal du chancre scléroderrien des coniferes, est un champignon pathogène très dommageable pour nos forêts de pins. En Amérique du Nord, la maladie se retrouve dans le nordest des États-Unis et dans l'est du Canada. Les résultats des relevés à travers le Canada depuis 1979 nous permettent de cartographier la distribution de la maladie. Ȧ Terre-Neuve, seule la race EU a été relevée et elle est restreinte à la péninsule d'Avalon. Contrairement à ce qui a été rapporté antérieurement dans les provinces Maritimes, seulement une plantation de pins est infectée par la race EU au Nouveau-Brunswick. En Ontario, un total de 171 plantations sont infectées et elles sont groupées dans la portion centrale du sud de la province. Les 749 plantations infectees par la race EU au Québec représentent le plus grand nombre de tout le Canada. Dans les quatre provinces, le pin rouge est l'espèce la plus infectée ( $86 \%$ des plantations infectées) suivi par deux espèces exotiques, le pin sylvestre $(9,5 \%)$ et pin noir d'Autriche $(3,2 \%)$. Le pin blanc et le pin gris montrent de la résistance à la maladie.

Mots clés: Brunchorstia pinea, Pinus resinosa, reboisement, Scleroderris lagerbergii

to have damaged trees in pine plantations years before its identification in Ontario (Dorworth 1970), and as early as 1933 at Valcartier, Quebec (Laflamme 1995).

The EU race was likely introduced into North America earlier this century from Europe (Hamelin et al. 1996). In North America, the EU race was first reported in New York State, in the United States (Dorworth et al. 1977, Setliff et al. 1975) where it caused extensive mortality and damage to semimature stands of red pine (Pinus resinosa Ait.) over an area of 14,000 ha (Skilling 1977). Following the outbreak in New York, the EU race was found in other states: New Hampshire, Maine and Vermont (Skilling et al. 1986). In Canada, the EU race was first isolated from red pine plantations in Quebec in 1978 (Lachance 1979), in Newfoundland in 1980 (Singh et al. 1980) and in Ontario in 1985 (Myren and Davis 1986). Since these dates, the EU race has increased its range in Ontario (Hopkin and McKenney

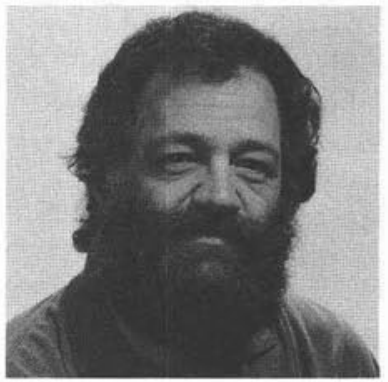

G. Laflamme

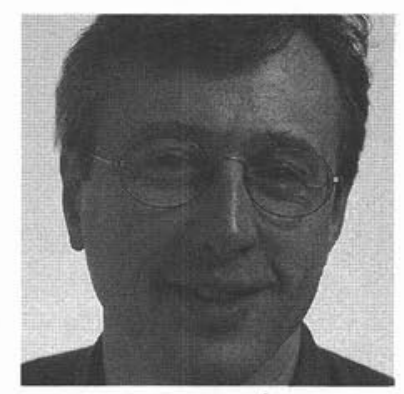

A.A. Hopkin

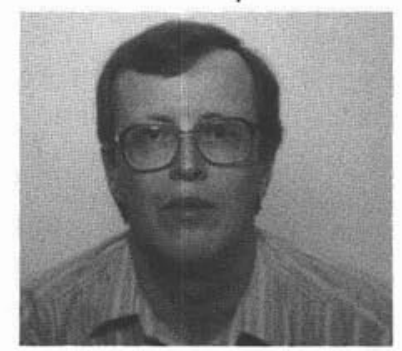

K.J. Harrison 
1995) and Quebec (Moody 1992). Although the EU race was first reported in New Brunswick in 1979 (Magasi 1982), these identifications were not clear. These mixed results were said to be caused by a bad batch of serum.

It has been demonstrated that the NA race infects trees generally under snow cover (Marosy et al. 1989), thus limiting the spread to a maximum of $2 \mathrm{~m}$ above ground. The EU race is not limited to this niche, and can infect the crowns of large trees (Laflamme 1991, Setliff et al. 1975). The EU race has been reported as having a broader host range than the NA race (Skilling et al. 1986). Recently, some concern has been shown regarding the ability of the EU race to extend its range into western Canada on lodgepole pine (Pinus contorta Dougl.) (Dorworth and Muir 1993) as it has been shown to have a significant impact on this species in Sweden (Karlman et al. 1994).

Contradictory results on race identification between different methodologies used on the same isolates have been recorded, creating confusion for the foresters having to deal with the disease (Petrini et al. 1989). Fortunately, race identification methodology has improved since races of G. abietina were first recognized in 1975 (Hamelin et al. 1993). This has allowed for clarification of isolates that were in question and helps us to better determine the distribution of the disease. Published maps on the distribution of the EU race in Canada are not up to date and contain errors related to this misidentification (Sterner 1984, Skilling et al. 1986, Hopkin and McKenney 1995).

The objectives of this study were to confirm the historical distribution of the EU race of $G$. abietina recorded in Canada since 1979 and to record the frequency of host species reported to be infected by the disease. Recommendations follow this update.

\section{Methods}

\section{Surveys}

Most of the surveys were conducted by the staff of the former Forest Insect and Disease Survey (FIDS) of the Canadian Forest Service in Newfoundland, the Maritime provinces, Quebec and Ontario. In Quebec, the staff of the Department of Natural Resources (MRN-Québec) conducted special surveys for Scleroderris canker from 1985 to 1990 . Using reforestation data, pine plantations were located on maps and then visited. In the field, technicians were looking for symptoms of the disease such as foliage coloration at the base of the trees, reddening at the base of the needles in early summer, cankers on trunks and greenish coloration under the bark of the shoots or the trunk and fruiting bodies of the fungus on the infected part of the trees. Samples were collected for diagnosis in the laboratory where the causal agent, when present, was isolated in pure culture for race identification.

In Newfoundland, annual surveys were conducted mainly on the Avalon Peninsula where the disease was first reported. Repeated surveys have been done in natural red pine stands in central Newfoundland and on Sitka spruce plantations around the island after the discovery of another Gremmeniella sp. on this species at Roddickton, but there is no indication that EU is present outside of the Avalon Peninsula.

In the Maritimes, annual Scleroderris detection surveys were conducted by FIDS staff beginning when the first infected plantation was detected in New Brunswick in 1971. Intensive surveys were conducted in cooperation with provincial and for- est industry staff in 1978 and 1979 to detect areas where the EU race might be present.

By 1981, eleven locations were found in New Brunswick where the EU, some "intermediate" or "non-North American" race of Scleroderris, was believed to occur (Magasi 1988). Repeated surveys were conducted during the 1980's but until 1988 only the NA race was detected.

In Nova Scotia, Scleroderris was first detected in 1972. By the time that race testing began in 1978, the disease had disappeared from all Nova Scotia locations. All of the damage observed between 1972 and 1978 occurred on small trees and at heights below 2 $\mathrm{m}$, so there is no evidence that the EU race was ever present in the province. No Scleroderris canker has been found in Nova Scotia in spite of repeated surveys since 1978.

In Prince Edward Island, no Scleroderris canker has ever been found during repeated detection surveys.

In Quebec, where the outbreak of Scleroderris canker is more important, several special surveys have been conducted over the years. In 1979 and 1980, federal and provincial staff conducted a special survey in a $10 \mathrm{~km}$ corridor along the QuebecUS border after the first discovery of the European race in Canada in 1978. In 1983 and 1984, the FIDS staff carried out a special survey in the valleys of the Gatineau, La Lièvre and Rouge rivers where the European race was discovered in 1983. From 1985 to 1990 , the staff of the MRN-Québec conducted a special survey on Scleroderris canker over the different regions of the province, starting in the south in 1985 and ending in 1990 in northern regions where red pine is planted.

In Ontario, Scleroderris canker was routinely assessed as part of annual plantation assessments. Beginning in 1978, a formal survey was undertaken by the FIDS Unit to detect the presence of the EU race of Scleroderris, south of $46^{\circ} \mathrm{N}$ as described by Hopkin and McKenney (1995). The Scleroderris field program was comprised of both an aerial and a ground survey. After 1990, the survey was restricted to pine plantations north of $44^{\circ} \mathrm{N}$ as the disease was not collected south of this latitude. Ground and aerial surveys were conducted from late May to mid-June. At each plantation visited, a minimum of 500 trees was inspected. Samples from trees that were suspected to be diseased were submitted for confirmation and race identification. The location of each sample and the race determination was recorded for every plantation. In addition, a record was made of each plantation where the disease was not observed.

In Manitoba, Saskatchewan, Alberta, and British Columbia, formal surveys for the disease were not undertaken. However assessment of whether the disease was present was done during routine stand evaluations.

\section{Isolation}

Usually, the fungus was isolated in pure cultures from conidia produced in cryptopycnidia (Cauchon and Lachance 1980); this type of fruiting body is covered by bark and is less contaminated by other microorganisms. Isolations were also made from portions of pycnidia, apothecia and wood chips from infected tissue.

\section{Race Identification}

The first method used for race identification was serology (Dorworth and Krywienczyk 1975). This method was utilized in Ontario for all race identifications in this study and a reliable serum was used. In 1982, a new method using electrophoresis gel (PAGE) was used and soon after adopted for 
Table 1. Confirmed locations of $G$. abietina, European race, by hosts in Ontario, Quebec, New Brunswick (N.B.) and Newfoundland (Nfld.) 1978 to 1996 . Each location may represent more than one isolate.

\begin{tabular}{lccccr}
\hline Host species & Ontario & Quebec & N.B. & Nfld. & Total (\%) \\
\hline P. resinosa & 163 & 658 & 0 & $7^{1}$ & $828(86.3)$ \\
P. sylvestris & 6 & 81 & 1 & 4 & $92(9.5)$ \\
P. nigra & 1 & 3 & 0 & $27^{2}$ & $31(3.2)$ \\
P. banksiana & 0 & $6^{3}$ & 0 & 1 & $7(0.7)$ \\
P. strobus & 1 & 1 & 0 & 0 & $2(0.2)$ \\
Total & 171 & 749 & 1 & 39 & $960(100)$ \\
\hline
\end{tabular}

${ }^{1}$ Including three large plantations.

${ }^{2}$ All ornamental trees in the vicinity of St. John's.

${ }^{3}$ Jack pine planted under heavily infected red pine.

all the other provinces (Ouellette et al. 1988). A more recent method using randomly amplified DNA (RAPD) markers has greatly reduced the time required for race identification by using infected material directly, as this does not require pure cultures (Hamelin et al. 1993), but this has only been used recently in routine identification. In the present study, all isolates that tested positive for the EU race or produced unclear results with serology were tested again with electrophoresis for Quebec and the Atlantic provinces.

\section{Results and Discussion}

A total of 960 distinct locations have been found to have trees infected with the EU race of G. abietina since 1978 (Table 1 and Fig. 1). In most areas, a location corresponds to a plantation greater than 4 ha, but isolates collected from Austrian pine (Pinus nigra Arnold) in Newfoundland were from individual, ornamental trees growing in rows or groups.

In Newfoundland, the disease is confined to the Avalon Peninsula. The disease was first recorded in 1979 near the city of St. John's (Singh et al. 1980) on ornamental Austrian pine and has been collected from other pine species since that date. A disease sample taken from a plantation of Sitka spruce (Picea sitchensis (Bong.) Carrière) on the west coast of Newfoundland was reported to belong to the EU race (Kondo and Moody 1987), but was later confirmed as G. abietina var. balsamea Petrini et al., a variety that will not infect pines (Bérubé et al. 1995). The NA race has not been found in Newfoundland, as all isolates identified there are of the EU race. This is quite logical as the NA race is most likely a native fungus on jack pine (Laflamme 1993) and that species does not occur naturally in Newfoundland. There are natural red pine stands in Central Newfoundland but the disease has never been found in this area. Scleroderris canker is confined to the Avalon Peninsula and quarantine regulations seem to have kept the disease inside this area. It was probably introduced on ornamental trees (Austrian pine) and seedlings of Scots and red pine imported for reforestation. The hypothesis of several introductions of the disease in Newfoundland was presented earlier (Laflamme 1993). A recent study (Hamelin et al. 1998) shows that the introduction of the disease on the island was from a different origin than the introduction on the mainland.

In New Brunswick, the European race has been isolated from only one location. Earlier reports (Magasi 1988) noted that the EU race or the so-called "non-North American race" was present at a variety of locations in the province. However, subsequent testing with RAPDs has determined these to be the NA race with the exception of the one isolate collected from Scots pine in a plantation near Bourgoin, in Madawaska County. The
EU race was originally detected at this location in 1988 and again in 1995 .

These results change the picture of the EU race in the Maritimes since only one plantation is now known to be infected. Appropriate measures taken in that plantation could eradicate the disease from New Brunswick and the Maritime provinces as a whole, leaving only the native NA race in New Brunswick.

In Quebec, the distribution of the EU race is dramatically different from that published earlier (Sterner 1984, Skilling et al. 1986). From 1978 to 1981, surveys were conducted near the New York State border where the EU race was thought to have originated. But the unexpected discovery of the EU race away from that region changed the picture. In 1983 six plantations in southwestern Quebec were found to be infected by G. abietina, which subsequent testing showed to be the EU race (Lachance et al. 1985). A survey of the region followed, and 121 plantations were found to contain the EU race (Laflamme and Lachance 1987). In one plantation located at Kazabazua, there were even cankers on dead and dying trees. The age of these cankers indicated that the disease was there approximately the year it was reported in New York State in 1975 (Laflamme 1997). These findings were followed by additional surveys throughout the province of Quebec from 1985 to 1990, which showed that the disease had spread throughout the range of red pine distribution where red pine had been planted more intensively. The number of infected plantations in Quebec may have been overestimated. Over a period of 12 years, two separate organizations have conducted surveys: FIDS staff from the Laurentian Forestry Centre and the Quebec Department of Natural Resources (MRN-Québec). Many plantations have been sampled by both organizations. We have eliminated many overlaps but a certain incompatibility between the two systems indicates that we have to be cautious and the overlaps could vary from 0 to $16 \%$. This variation does not change the geographical distribution of the disease. Outside the 731 infected plantations and concentrated in the southern part of the province (Fig. 1), there are 18 more isolated locations. One is a tree nursery near the northern part of the Quebec-Ontario border, eight are distributed on the Gaspé Peninsula with two red pine plantations along the New Brunswick border, and nine are dispersed in the extensive region of Lac Saint-Jean and the North Shore. A large number of these infected plantations have been pruned by the staff of the MRN-Québec or private organizations to control Scleroderris canker, but we do not know the proportion of these plantations that are still infected.

In Ontario, the EU race was reportedly collected at two locations in 1985 (Myren and Davis 1986). However, a late collection showed the disease to actually be present at three separate locations in that year (Sajan and Smith 1986), with each being 30 to $100 \mathrm{~km}$ from the other. All three collections came from red pine plantations in the central part of southern Ontario, $225 \mathrm{~km}$ west of the nearest known location of the EU race. A control program involving sanitation (Hopkin and Laflamme 1995, Hopkin and McKenney 1995) was conducted in these areas. However, an expanded survey in 1986 found the EU race in nine locations and this increased to 42 plantations by 1995 (Evans et al. 1996), the last year of a formal FIDS survey for Scleroderris in Ontario. In spite of the increase in the number of infected plantations, the EU race remains confined to a relatively small geographic area, as compared with the distribution in Quebec (Fig. 1). In Ontario, about half of the plantations infected 


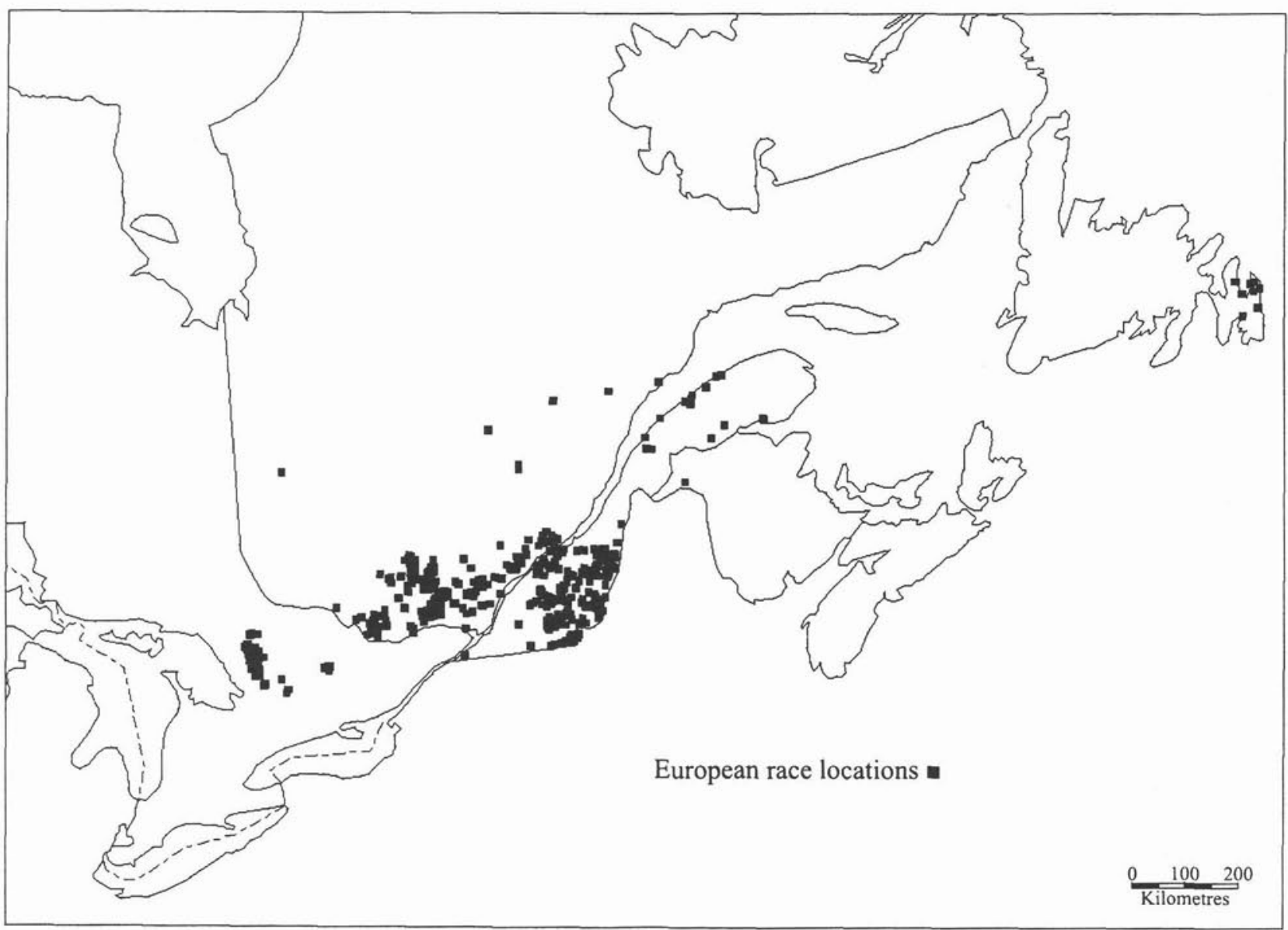

Fig. 1. Distribution of the European race of Gremmeniella abietina in Canada in 1997.

with the EU race were found in one township. As of 1995, the EU race remained absent from eastern Ontario in spite of its occurrence in western Quebec (Fig. 1).

The EU race still appears to be absent from western Canada. This is significant since lodgepole pine, a widespread forest species in western Canada, was extremely susceptible to the EU race when grown as an exotic plantation species in Scandinavia (Karlman et al. 1994). It underlines the importance of preventing the introduction of the EU race into western Canada, as suggested by Dorworth and Muir (1993).

In Canada, the largest number of locations where the EU race has been found is in Quebec with 78\% of all locations, followed by Ontario with $18 \%$ and Newfoundland with $4 \%$ (Table 1). Only one location has been found in New Brunswick since 1988. The EU race has not been detected in any of the other provinces. The EU race has the capacity to infect all native pine species in eastern Canada with the possible exception of pitch pine (Pinus rigida Mill.), which is restricted to only a few sites along the St. Lawrence River in Ontario and Quebec (Farrar 1995). However, red pine is the most affected species as it represents $86 \%$ of all plantations infected with the EU race (Table 1) and it is the only native species to sustain damage by the EU race. White pine from which the NA race was originally isolated in Ontario (Hopkin and Davis 1998) has only been recorded on one occasion each in Quebec and Ontario, the latter not until 1995. Only trace damage is observed on white pine foliage infected by the EU race. The same observation was noted in New York
State where red pine plantations were killed by the EU race of G. abietina while white pine growing in the stands did not show symptoms of the disease (Fig. 2). Similarly, jack pine is almost free of the disease (Laflamme and Blais 1998) but can be severely damaged by the NA race. When jack pine is infected by the EU race, it shows only limited damage to the foliage as only 1 to $2 \mathrm{~cm}$ of the shoots is killed and the disease does not progress any further. The introduced Austrian and Scots pines are both infected by the EU race. Scots pine is more frequently infected than the other native species, jack pine and white pine. Austrian pine is grown primarily as an ornamental and as such has been the prime host for the EU race in Newfoundland (Table 1), although it reportedly is less damaged than red pine (Bérubé et al. 1995).

To answer the question as to when the disease began and from where it originated, studies on the pathogen population with molecular biology techniques will provide some answers. The introductions into Newfoundland are different from the one on the continent (Hamelin et al. 1998) with the exception of Ontario where the population study has not yet been done. The EU race was probably introduced from Europe through infected seedlings and multiple introductions have been suggested (Hamelin et al. 1996). But even if the race is called European, it seems evident that the so-called EU race may have been introduced into Europe itself from somewhere else. The genetic variability of the EU race in Europe is very low if compared with the NA race (Hamelin et al. 1996, Hantula and Muller 1997). 


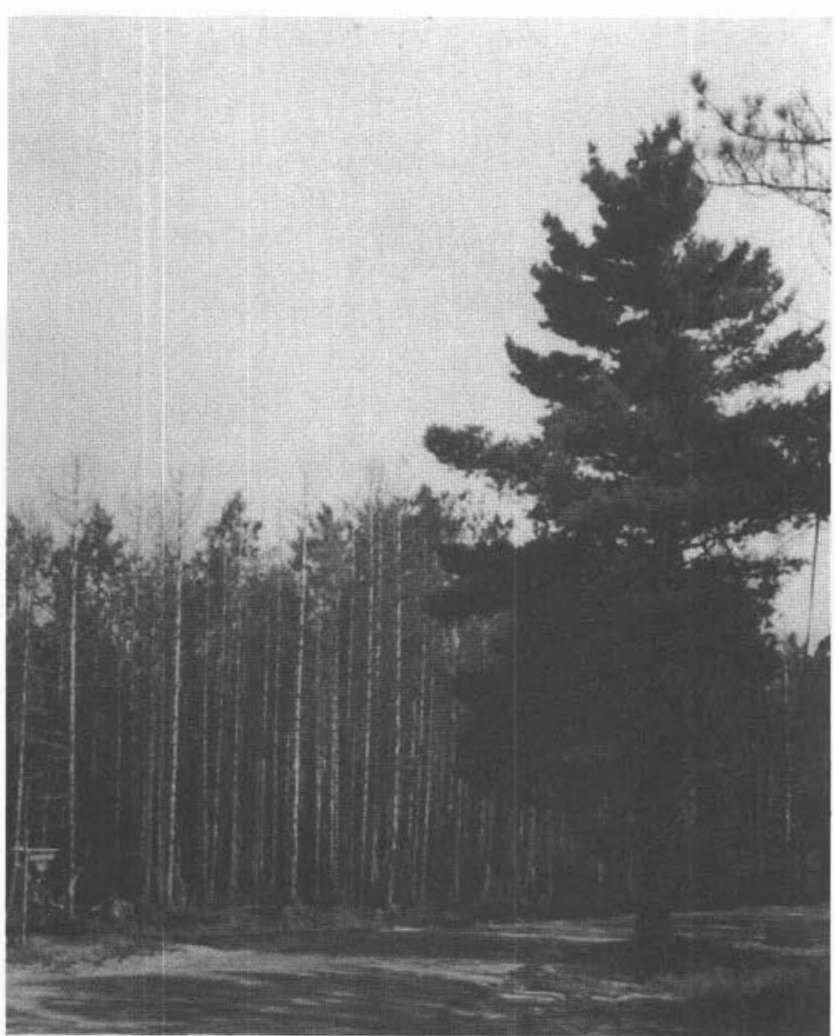

Fig. 2. Living white pine in a red pine plantation killed by the European race of Gremmeniella abietina, in New York State in 1978 (photo: G. Laflamme).

Recent work has shown that three distinct biotypes of the EU race exist in Europe. Two of these biotypes (one located in the Alps and the other in Scandinavian countries) develop under the snow like the NA race while the third biotype has a panEuropean distribution and is the same as the EU race found in North America (Hamelin et al. 1996).

If there is no doubt that the EU race was introduced into Canada, it is more difficult to know when and how it was done. The pattern of distribution of the disease in southwestern Quebec (Fig. 1), where the pathogen is prevalent in red pine plantations but absent on the Ontario side of the Ottawa River, strongly suggests that infected nursery material was involved in spreading the disease. The first author, when working for Quebec's Ministère des Terres et Forêts, demonstrated that stocks of red pine seedlings produced in 1977 and 1978 in three provincial nurseries were infected with Scleroderris canker prior to reforestation (Laflamme 1979a, 1979b, 1980). At that time, foresters were not familiar with the symptoms and it was difficult to detect the disease on bare root seedlings in early April. In 1978, thousands of infected seedlings from these tree nurseries were destroyed but we did not know if the EU race was involved as no tests were conducted. At that time, it was believed that the EU race was only in New York State and we were supposed to be dealing with the NA race only. From 1979 on, a phytosanitary inspection was carried out and a certificate was needed to move the seedlings out for reforestation. From these inspections, the EU race was identified in six different tree nurseries. In Ontario, the pattern of distribution of the disease in 1985 was also indicative of the distribution of infected seedlings. However, Ontario had previ- ously embarked on a chemical control program for nursery stock. In New York and Vermont States, it is also obvious that infected seedlings were responsible for the spread of the EU race (Bergdahl et al. 1996, Skilling et al. 1986).

In the Maritime provinces, bare root seedlings of Pinus spp. are no longer grown in commercial quantities by provincial, forest industry or small private nurseries. With the switch to container-grown nursery seedlings and the removal of susceptible pine windbreaks around nurseries in the 1980 s, the risk of outplanting stock infected with EU race was reduced dramatically.

The distribution of the EU race is limited to eastern Canada and red pine is the most affected species. It seems likely now that the EU race was introduced into North America, but the spread of the disease within the country seems to be related to the distribution of infected seedlings from tree nurseries and control of the disease in nurseries with a phytosanitary inspection before shipping the seedlings should stop the spread of the disease to new locations. The actual infected plantations can be treated by pruning (Laflamme 1997) and it is even possible to think about eradication, as the fungus of the EU race produces only conidia that are associated with short-distance dispersal. But ornamental trees can also spread the disease, as was the case in Newfoundland, and the transportation of these trees is difficult to regulate. We should avoid carrying seedlings or living trees from infected areas into non-infected ones; this is particularly important for western Canada where lodgepole pine, a susceptible species under Swedish conditions, could be severely damaged by the EU race.

\section{Acknowledgements}

We gratefully acknowledge the field observations and collections made by the field staff of the former Forest Insect and Disease Survey units of the Canadian Forest Service, and the Ministère des Ressources naturelles du Québec. We would also like to thank Ms. N. Lecours from the Laurentian Forestry Centre and Mr. C. Davis from the Great Lakes Forestry Centre for race identifications as well as Mr. T. Dumond from the Great Lakes Forestry Centre for Handling the data bank and map creation.

\section{References}

Bergdahl, D.R., R. Kelley and H.B. Teillon. 1996. History of Scleroderris canker in Vermont (1971-1996). Phytopathology 86: S119. Bernier, L., R.C. Hamelin and G.B. Ouellette. 1994. Comparison of ribosomal DNA length and restriction site polymorphisms in Gremmeniella and Ascocalyx isolates. Appl. Environ. Microbiol. 60: $1279-1286$

Bérubé, J.A., G.C. Carew, G. Laflamme, and G.R. Warren. 1995. Cross infectivity of scleroderris canker on native and exotic conifers in Newfoundland. pp. 234-239 in P. Capretti, U. Heiniger and R. Stephan (eds). Shoot and foliage diseases in forest trees. Proceedings of a joint meeting of the IUFRO working parties, canker and shoot blight of conifers (S2.06.02), foliage diseases (S2.06.04). June 6-11, 1994. Vallombrosa, Firenze, Italy. 309 p.

Cauchon, R. and D. Lachance. 1980. Recherche de cryptopycnides, pour un diagnostic précoce de Gremmeniella abietina. Can. J. Plant Pathol. 2: 232-234.

Dorworth, C.E. 1970. Scleroderris lagerbergii Gremmen and the pine replant problem in central Ontario. Dep. Fish. For., Can. For. Serv., Sault Ste. Marie, Ont. Inf. Rep. O-X-139. 12 p.

Dorworth, C.E. and J. Krywienczyk. 1975. Comparisons among isolates of Gremmeniella abietina by means of growth rate, conidia measurement, and immunogenic reaction. Can. J. Bot. 53: 2506-2525. Dorworth, C.E. and J.A. Muir. 1993. Constraint of trans-continental spread of Gremmeniella abietina in Canada. pp. 111-122 in P. 
Barklund, S. Livsey, M. Karlman, and R. Stephan (eds). Shoot diseases of conifers. Proceedings of an international symposium. Garpenberg, Sweden, 10-15 June 1991. Swedish University of Agricultural Science, Uppsala, Sweden.

Dorworth, C.E., J. Krywienczyk and D.D. Skilling. 1977. New York isolates of Gremmeniella abietina (Scleroderris lagerbergii) identi$\mathrm{cal}$ in immunogenic reaction to European isolates. Plant Dis. Rep. 61: 887-890.

Evans, H.L., W.A. Ingram, P.M. Bolan, C.G. Jones, and S.G. Payne. 1996. Results of forest insect and disease surveys in the central region of Ontario 1995. Nat. Resour. Can., Can. For. Serv., Sault Ste. Marie, Ont. Inf. Rep. O-X-453. 39 p.

Farrar, J.L. 1995. Trees in Canada. Nat. Resour. Can., Can. For. Serv., Ottawa, Ont. 502 p.

Gibbs, J.N.G. 1993. Scleroderris canker, North American and European strains in Canada. pp. 32-41 in P. Barklund, S. Livsey, M. Karlman, and R. Stephan (eds). Shoot diseases of conifers. Proceedings of an international symposium. Garpenberg, Sweden, 10-15 June 1991. Swedish University of Agricultural Science, Uppsala, Sweden.

Hamelin, R.C., N. Lecours, P. Hansson, M. Hellgren, and G. Laflamme. 1996. Genetic differentiation within the European race of Gremmeniella abietina. Mycol. Res. 100: 49-56.

Hamelin, R.C., N. Lecours and G. Laflamme. 1998. Molecular evidence of distinct introductions of the European race of Gremmeniella abietina into North America. Phytopathology 88: 582-588.

Hamelin, R.C., G.B. Ouellette and L. Bernier. 1993. Identification of Gremmeniella abietina races with random amplified polymorphic DNA markers. Appl. Environ. Microbiol. 59: 1752-1755.

Hantula, J. and M.M. Muller. 1997. Variation within Gremmeniella abietina in Finland and other countries as determined by random amplified microsatellites (RAMS). Mycol. Res. 101: 169-175.

Hopkin, A.A. and C.N. Davis. 1998. The host range and geographic distribution of the North American and European races of Gremmeniella abietina in Ontario. In G. Laflamme, J.A. Bérubé and R.C. Hamelin (eds). Proceedings of the IUFRO WP 7.02.02 Meeting on Foliage, Shoot and Stem Diseases of Trees. May 25-31, 1997, Quebec City, Quebec, Canada. Nat. Resour. Can., Can. For. Serv., Inf. Rep. LAU-X-122.

Hopkin, A.A. and G. Laflamme. 1995. The distribution and control of scleroderris disease in Ontario. Nat. Resour. Can., Can. For. Serv. - Sault Ste. Marie. Tech. Note No. 21, 4 p.

Hopkin, A.A. and D.W. McKenney. 1995. The distribution and significance of scleroderris disease in Ontario. Nat. Resour. Can., Can. For. Serv. - Ontario. NODA/NFP Tech. Rep. TR-7. 11 p.

Karlman, M., P. Hansson and J. Witzell. 1994. Scleroderris canker on lodgepole pine introduced in northern Sweden. Can. J. For. Res. 24: 1948-1959.

Kondo, E.S. and B.H. Moody. 1987. Forest insect and disease conditions in Canada 1986. Can. For. Serv., Ottawa, Ont. 128 p.

Lachance, D. 1979. Découverte de la souche européenne de Gremmeniella abietina au Québec. Phytoprotection 60: 168.

Lachance, D., P. Benoit, G. Laflamme, and R. Picher. 1985. Insectes et maladies des arbres. Quebec 1984. Suppl. For. Conserv. $51.28 \mathrm{p}$.

Laflamme, G. 1979a. Chancre scléroderrien en plantation: Pins rouges plantés dans la Région administrative du Nord-Ouest en 1977. Rapport interne. Ministère des Terres et Forêts du Québec, Direction de la Conservation. $11 \mathrm{p}$.

Laflamme, G. 1979b. Chancre scléroderrien en plantation: Pins rouges plantés dans la Région administrative des Cantons de l'Est en 1978. Rapport interne. Ministère des Terres et Forêts du Québec. Direction de la Conservation. $17 \mathrm{p}$.

Laflamme, G. 1980. Chancre scléroderrien en plantation: Pins rouges provenant de Normandin et plantés en 1977. Rapport interne. Ministere des Terres et Forêts du Québec, Direction de la Conservation. $14 \mathrm{p}$.

Laflamme, G. 1991. Scleroderris canker on pine. Forestry Canada - Quebec Region, Sainte-Foy, Quebec, Inf. Leafl. LFC 3. 12 p.

Laflamme, G. 1993. Scleroderris canker, North American and

European strains in Canada. pp. 59-67 in P. Barklund, S. Livsey, M. Karlman, and R. Stephan (eds). Shoot diseases of conifers. Proceedings of an international symposium. Garpenberg, Sweden, 10-15 June 1991. Swedish University of Agricultural Science, Uppsala, Sweden. Laflamme, G. 1995. The earliest report of scleroderris canker in North America. pp. 210-213 in P. Capretti, U. Heiniger and R. Stephan (eds). Shoot and Foliage Diseases in Forest Trees. Proceedings of a Joint Meeting of the Working Parties Canker and Shoot Blight of Conifers, Foliage Diseases. Vallombrosa, June 6-11, 1994. Firenze, Italy.

Laflamme, G. 1997. Traitement réussi, en plantation de pins rouges, d'une épiphytie de chancre scléroderrien, race européenne. Phytoprotection 78: 91.

Laflamme, G. and R. Blais. 1998. Pinus banksiana not damaged by the European race of scleroderris canker. In G. Laflamme, J.A. Bérubé and R.C. Hamelin (eds). Proceedings of the IUFRO WP 7.02.02 Meeting on Foliage, Shoot and Stem Diseases of Trees. May 25-31, 1997, Quebec City, Quebec, Canada. Nat. Resour. Can., Can. For. Serv., Inf. Rep. LAU-X-122.

Laflamme, G. and D. Lachance. 1987. Large infection center of scleroderris canker (European race) in Quebec province. Plant Dis. 71: 1041-1043.

Magasi, L.P. 1982. Forest pest conditions in the Maritimes in 1981. Environ. Can., Can. For Serv., Maritimes For. Res. Centre, Inf. Rep. M-X-135.

Magasi, L.P. 1988. Forest pest conditions in the Maritimes in 1987. Can. For. Serv. - Maritimes, Inf. Rep. M-X-166.

Marosy, M., R.F. Patton and C.D. Upper. 1989. A conducive day concept to explain the effect of low temperature on the development of scleroderris shoot blight. Phytopathology 79: 1293-1301.

Moody, B.H. (comp.) 1992. Forest insect and disease conditions in Canada 1989. Forestry Canada, Ottawa, Ont.

Myren, D.T. and C.D. Davis. 1986. European race of scleroderris canker found in Ontario. Plant Dis. 70: 475.

Ouellette, G.B., N. Benhamou, N. Lecours, and D. Lachance. 1988. Investigations on new means of identifying races of Ascocalyx abietina. pp. 73-79 in E. Donaubauer and B.R. Stephan (eds). Recent research on scleroderris canker of conifers. Mitteilungen der forstlichen Bundesversuchanstalt Wien No. 163. Osterreichischer Agrarverlag, Vienna.

Petrini, O., L.E. Petrini, G. Laflamme, and G.B. Ouellette. 1989. Taxonomic position of Gremmeniella abietina and and related species: a reappraisal. Can. J. Bot. 67: 2805-2814.

Petrini, O., L. Toti, L.E. Petrini and U. Heiniger. 1990. Gremmeniella abietina and $G$. laricina in Europe: characterization and identification of isolates and laboratory strains by soluble protein electrophoresis. Can. J. Bot. 68: 2629-2635.

Punter, D. 1967. Scleroderris lagerbergii Gremmen, a new threat to nurseries in northern Ontario. For. Chron. 43: 161-164.

Sajan, R.J. and B.E. Smith. 1986. Results of forest insect and disease surveys in the Algonquin region of Ontario, 1985. Can. For. Serv., Sault Ste. Marie, Ont. Misc. Rep. No. 40.45 p.

Setliff, E.C., J.A. Sullivan and J.H. Thompson. 1975. Scleroderris lagerbergii in large red and Scots pine trees in New York. Plant Dis. Rep. 59: 380-381.

Singh, P., C.E. Dorworth and D.D. Skilling. 1980. Gremmeniella abietina in Newfoundland. Plant Dis. 64: 1117-1118.

Skilling, D.D. 1977. The development of a more virulent strain of Scleroderris lagerbergii in New York State. Eur. J. For. Pathol. 7: 297-302.

Skilling, D.D., B. Schneider and D. Fasking. 1986. Biology and control of Scleroderris canker in North America. USDA For. Serv., St. Paul, MN. Res. Rep. NC-275. 18 p.

Sterner, T.E. 1984. Scleroderris canker, Gremmeniella abietina (Lagerb.) Morelet, in Canada - An overview. pp. 8-10 in P.D. Manion (ed). Scleroderris canker of conifers. Proceedings of an international symposium, Syracuse, N.Y., USA. June 21-24, 1983. Martinus Nijhoff/Dr. W. Junk Publishers, The Hague, Netherlands. $273 \mathrm{p}$.

Yokota, S., T. Uozumi and S. Matsuzaki. 1974. Scleroderris canker of Todo-Fir in Hokkaido, Northern Japan. I. Present status of damage, and features of infected plantations. Eur. J. For. Pathol. 4: $65-74$. 